\title{
Properties of Command Constructions in TiD
}

\author{
A. Sumru Özsoy ${ }^{1}$, Meltem Kelepir ${ }^{2}$, Derya Nuhbalaoğlu ${ }^{3}$, Emre \\ Hakgüder $^{4}$ \\ ${ }^{1,2}$ Boğaziçi Üniversitesi, Fen-Edebiyat Fakültesi, Dilbilim Bölümü, John Freely Binası, \\ 34342, Bebek, İstanbul \\ ${ }^{3}$ Georg-August-Universität Göttingen, Seminar für Deutsche Philologie Courant \\ Forschungszentrum “Textstrukturen” Nikolausberger Weg 23, 37073 Göttingen, Germany \\ ${ }^{4}$ The University of Chicago, Department of Linguistics 1115 E. 58th Street, Rosenwald Hall \\ Room 224 Chicago, IL 60637 \\ I'ozsoys@boun.edu.tr, ${ }^{2}$ meltem.kelepir@boun.edu.tr, ${ }^{3}$ derya.nuhbalaoglu@uni- \\ goettingen.de, ${ }^{4}$ emre.hakguder@gmail.com \\ (Received 8 December 2017; accepted 9 June 2018)
}

\begin{abstract}
This paper focuses on the properties of command constructions in Turkish Sign Language (TID). The nature and function of manual signs and nonmanual markers in command constructions in TID are investigated to determine their prosodic, morphological, morphophonological, and syntactic properties. We show that TID does not utilize any of the properties reported in the literature as an obligatory marker of commands in some spoken and sign languages. The only salient marker of commands we have identified is a nonmanual marker: (forward/sideward) head tilt ${ }^{1}$.
\end{abstract}

Key words: command, manuals, nonmanuals, Turkish Sign Language

\section{TID'de Buyurma Yapılarının Özellikleri}

ÖZ: Bu çalışmada Türk İşaret Dili’ndeki (TID) emir yapıları incelenmektedir. Çalışmada TiD emir yapılarının ezgisel, biçimbirimsel, biçim-sesbilimsel ve sözdizimsel özelliklerini belirlemek amacıyla bu yapıların el ve el-dışı işaretlerinin niteliği ve işlevleri incelenmektedir. Bazı işitsel ve işaret dillerindeki emir yapılarında zorunlu oldukları belirlenmiş olan özelliklerden hiçbirini TİD'in yansıtmadığı gözlemlenmiştir. TİD emir yapılarının en

1 The research for this paper was fully supported by TÜBITAK project no $111 \mathrm{~K} 314$, which was part of the COST Action IS1006 "SignGram". Many thanks to all the TID signers who participated in this study.

We would also like to thank the following for their invaluable feedback: the organizer Caterina Donati, the invited speaker Sabine Iatridou and the other participating researchers at the "SignGram" workshops on imperatives in November 2012 and May 2013, the organizers and the audience of the Sign Language Workshop organized by the Japanese Linguistics Society, and the two anonymous reviewers. An earlier version of this paper appeared in Journal of Japanese Linguistics Society, 146.

The handshape fonts are created by CSLDS, CUHK.

http://dx.doi.org/10.18492/dad.373380

Dilbilim Araştırmaları Dergisi, 2018/1, 161-178.

(C) 2017 Boğaziçi Üniversitesi Yayınevi, İstanbul. 
belirgin özelliğinin el-dış1 işaret olan öne/yana baş eğmesi olduğu saptanmıștır.

Anahtar sözcükler: emir, el işaretleri, eldışı işaretler, Türk İşaret Dili

\section{Introduction}

This paper analyzes the properties of command constructions in Turkish Sign Language (TID). It investigates the nature and function of manual signs and nonmanual markers in command constructions in TID with the aim of determining the prosodic, morphological, morphophonological, and syntactic properties of the construction.

The imperative form, along with declaratives, interrogatives and exclamatives, is one of the basic sentence types in languages (Dryer, 2007: 224; König \& Siemund, 2007: 277 and 316). Research on spoken and sign languages has identified the common properties of constructions that have been considered imperatives. These properties include reduced verbal morphology, restricted expression of subjects, marked word order, requirement for a special construction such as the subjunctive in negative imperatives, and special intonation. $^{2}$

The imperative form and the function command illustrate a typical case of function-form mapping discrepancy in language. On the one hand, while the most typical linguistic function of the imperative form is command, it may also be used to express other functions such as giving instructions, making suggestions, inviting an interlocutor to participate and giving permission or directives. On the other hand, the function command may be expressed not only in the form of an imperative but also other construction types such as questions and declaratives with modals.

This study focuses on the most canonical function of the imperative form in Turkish Sign Language (TID), namely command, and investigates whether command constructions share any of the properties of imperatives that have been observed cross-linguistically in other sign languages ${ }^{3}$.

\footnotetext{
2 Another property reported for imperatives is the impossibility of embedding the imperative form under another speech act, although it has also been stated that this does not hold in all cases (Grimshaw, 1978). Other properties of imperatives include the possibility of occurring with a declarative for expressing a conditional (Iatridou, 2008; Portner, 2007; von Fintel \& Iatridou, 2010; Fintel \& Iatridou, 2017 and Donati et al., 2017).

3 Throughout the paper, we will mostly refrain from referring to the construction of our investigation as imperative, and refer to it as 'command construction', except when we discuss the morphological properties of the construction and contrast it with declaratives.
} 
While imperatives in spoken languages have been analyzed in typological (Aikhenvald, 2012) and theoretical studies (Iatridou, 2008; von Fintel \& Iatridou, 2012; Portner, 2004; Han, 2000; Zanuttini, 2008), very little is known about sign language imperatives (see Cecchetto, 2012 for an overview). Nevertheless, recent research on individual sign languages has revealed a number of cross-linguistic and language particular features of the form (Donati et al., 2017). Among the morphosyntactic properties listed as being distinctive of imperative/command constructions in sign languages are the absence of a subject pronoun (LSC, NSL), the absence of subject agreement on agreeing verbs, change in $\mathrm{VO} / \mathrm{OV}$ order (LSC), and a negative imperative form distinct from non-negative counterparts (NSL, LIS). Moreover, the following properties have also been reported to mark commands: intensity of the movement of the verb (LSC), body lean, repetition and directionality of the verb signs (PJM), a number of head-related nonmanuals such as head nod/head tilt (TID, NSL), furrowed brows (LSC, LIS, PJM), raised brows (LSF), and raised chin (PJM) ${ }^{4}$. Also commonly, but not exclusively, utterance final manual signs such as PALM-UP have been observed in the command constructions of a number of sign languages such as NGT (Maier et al., 2013)

The organization of the paper is as follows. Section 2 describes our methodology. Section 3 focuses on the morphological properties of the verb forms in commands. We specifically investigate whether verbs display reduction in aspectual or agreement morphology when they have a command function. Section 4 discusses the nonmanual marker head tilt. In Section 5, we turn to the syntactic properties of commands and discuss the presence or the absence of subject pronouns and the properties of negative commands. Section 6 discusses a potential manual marker PALM-UP. Section 7 summarizes our findings and concludes the paper.

\footnotetext{
4 See Alba et al. (2013) for LSC, Schröder et al. (2013) for NSL, Brynjólfsdóttir \& Jónsson (2013) for ÍTM, Zeshan (2003), Açan (2007) and Özsoy et al. (2013, 2015) for TID. Rutkowski (2013) notes that there is no single form dedicated to imperative but a number of optional strategies to mark imperative in PJM. Schröder et al. (2013) and Zeshan (2003) consider head nod as an imperative marker. Also see Donati et al. (2017) for a detailed discussion of imperatives in LIS, LSC, LSF.

5 Donati et al. (2017) discuss such manual signs in three sign languages: B-INDEX and MOVIMP, with different functions in LIS; MOVIMP $\mathrm{G}_{\mathrm{G}}$ (for commands) and MOVIMP $_{\mathrm{B}}$ (for all other imperatives but commands) in LSF; particles in $\mathrm{H}$-handshape (for commands) and $x$-handshape (polite request) in LSC. Schröder et al. (2013) report that manual articulators of positive imperatives in NSL are observed to have "two ] handforms with palms down and orientation out."
} 


\section{Methodology}

The participant profile, data collection procedure and the nature of elicitation tasks used in our experiments are as follows.

\subsection{Participant Profile}

Data analyzed in this study were elicited from 10 fluent deaf signers of TiD (3 male and 7 female) and one TiD-Turkish bilingual hard of hearing assistant who facilitated communication between the members of the research team and the deaf participants.

At the time of recording all participants were aged between 19-55. All participants had attended schools for the deaf, their levels of education ranged from primary school to university. They were (/are) all actively involved in the Deaf community in Istanbul.

\subsection{Data Collection Procedure}

Signers were asked to sit facing each other and to interact. We recorded instruction videos beforehand with the bilingual research assistant for each task. Data collection was monitored by the same assistant. Stimuli were presented either on a laptop computer or with the help of other visual materials (e.g. pictures, maps), all of which were located on a small table positioned between two signers. For recording, three HD camcorders, two of which faced the signers individually, were used, while the third captured the two signers sitting in one shot. Recordings took place at the Linguistics Laboratory at Boğaziçi University. The total length of footage recorded for this study was approximately 6 hours. The video files were edited on Adobe PremierePro and Media Encoder CS5.5, and the clips were annotated on ELAN (Sloetjes \& Wittenburg, 2008) by the same research assistant.

\subsection{Elicitation Tasks}

Tasks for eliciting both production and comprehension data were developed. The tasks had varying degrees of structuring aimed at eliciting utterances that individually convey command, recommendation, direction or permission

6 Our findings also support a recent study by Brentari, Falk, Giannakidou, Herrmann, Volk and Steinbach (2018) conducted on the properties of prosodic cues of imperatives in a sign language. Brentari and her co-researchers have found that commands, among the imperative constructions, are the most easily recognizable type for ASL signers. They found that properties of the prosodic cues specifically frequency and duration of the nonmanual to be the distinctive property in identifying the command construction. 
meanings. The production tasks' aims were to elicit: (i) responses to various situations described on pre-recorded videos signed by a native TID signer, (ii) responses to pictographic stimuli that imply positive or negative obligations, and (iii) linguistic directions on the map. The comprehension task involved identification of constructions (henceforth, construction identification task) and was designed to investigate the morphological properties of the command/imperative form ${ }^{7}$. This paper focuses on the results of the production tasks.

\section{Morphological Properties of Verbs in Commands}

With the assumption that investigated commands may help to identify the morphological properties of imperatives in TID, we analyzed the commands data with respect to the morphological properties that have been generally associated with imperatives. Among these properties are the reduced or special verbal inflections (observed in spoken languages) and the intensity and abruptness in the articulation of the verb (in sign languages) (Iatridou, 2008; Donati et al., 2017 among others). To observe the properties of the verbs in commands, we investigated the effect of telicity and agreement reduction in TID commands.

\subsection{Telicity and Commands}

We hypothesize that if reduction were a salient marker of commands in TiD, then we should be able to see a more prominent reduction in repetition visible in the phonology of atelic verbs in the imperative/command form than in perfective aspect. That sign languages make a phonological distinction between telic and atelic verbs was established by Wilbur (2010) in her Event Visibility

7 The construction identification task was developed to determine whether the signers could tell apart commands and statements without the help of a context. For this task, 15 vignettes with two human participants were recorded. Each vignette showed an agent acting on a patient or transferring a possession (i.e. an item) to a recipient/indirect object. A total of five ditransitive actions expressed by an agreement verb in TID were depicted. The verbs were TAKE, SHOW, PAY, ASK, and GIVE. In each vignette, the research assistant signed the verb in its perfective (past), imperfective (future) and command forms (a total of 15 sentences). The vignettes were then scrambled and shown to 10 fluent signers of TID ( 3 male, 7 female), where the participants were asked to identify the command construction. Each participant was given a card with an exclamation mark. The participants were instructed to raise the card every time they identified the sentence on the video as a command. If they identified the sentence as a declarative or did not identify it as a command, they did not take action and continued with the following video. The participants were allowed to watch the videos as many times as they wished. 
Hypothesis. While atelic verbs are articulated with repetitive movement, telic verbs are articulated with a single movement. We therefore investigated whether the so-called reduction could be better observed with verbs that exhibit repetition in their lexical form.

A verb such as cry is considered an atelic verb in TID. It is articulated with repetitive movement in its citation form and when uttered with continuous aspect as shown in (1a) below. The dominant hand ( $\mathrm{Y}$-handshape) is moved on the vertical plane twice in front of the glabella, as depicted in (1) below ${ }^{8}$ :

(1) a.

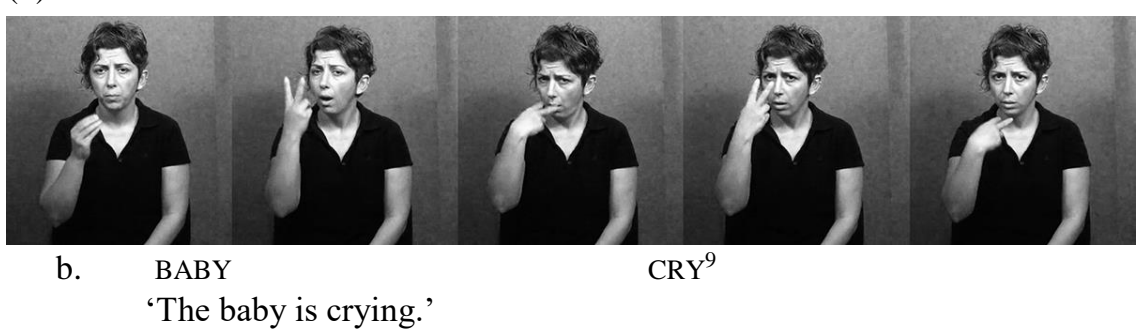

A verb such as BREAK, however, is telic and is articulated with a single movement:

8 We looked at a total of 29 verbs consisting of double and single agreement and plain verbs. 13 of these verbs were clearly telic and had a single movement in their citation form, such as SEND, ASK, BREAK, and WAKE.UP. 10 of them were clear examples of the atelic type such as TELL, CRY, FEED, LAUGH and RUN. For the sake of simplicity we only present out findings of a typically telic verb BREAK and a typically atelic verb CRY.

9 We follow the general convention in transcribing sign languages. Lexemes are represented by small capitals. The nonmanuals are represented above the lexeme with which they co-occur. The domain of the spreading of the nonmanual is represented by a line that has the abbreviation of the nonmanual at the right edge of the domain. The list of abbreviations and conventions used in the paper is given at the end of the paper. 
(2) a.

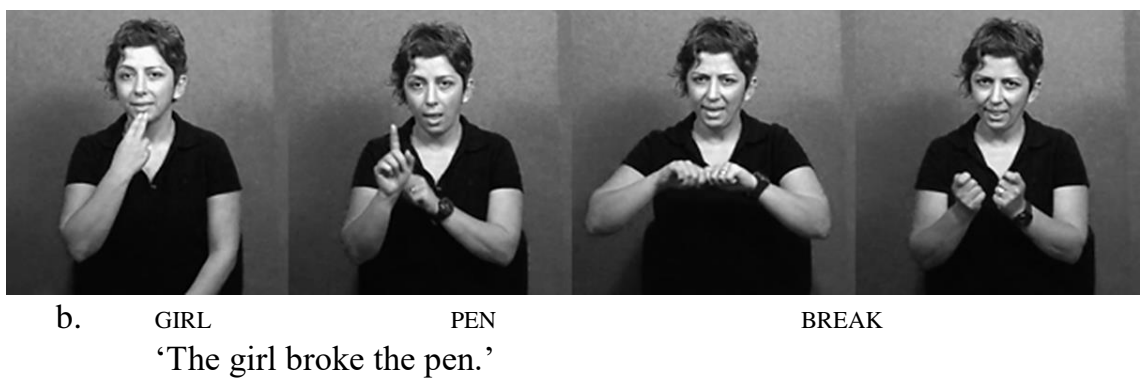

Contrary to our expectations, no reduction in the number of repetitions in the following example of command with cry, an atelic verb, was observed.

(3) a.

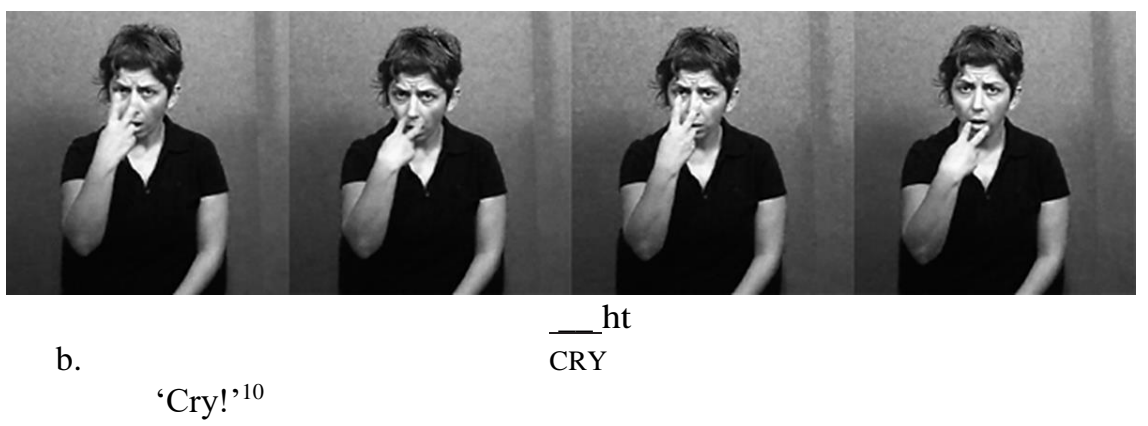

The only observable difference we found was that verbs in commands are signed with a higher degree of intensity than in a declarative frame. Thus, we conclude that the repetition of movement, which expresses a lexical aspectual feature (i.e. telicity), is preserved in commands.

We now turn to another potential case of reduction in commands, i.e. reduction in agreement morphology.

\subsection{Agreement}

Iatridou (2008) has shown that the verb in an imperative construction in spoken languages can be reduced to the root, or occur in an infinitival or participial

10 One reviewer has commented that the form of command construction might be incompatible with CRY. One might in fact consider a stage director in a play giving such a command to an actor in a play. 
form. Based on Iatridou's findings on multiple languages, albeit spoken, one can ask whether inflectional reduction on the verb is observed in sign languages as well (see Zhang, 1990; Mauck, 2005 as cited in Donati \& Branchini, 2012).

TID is considered to be an SOV language (Sevinç, 2006; Açan, 2007; Gökgöz \& Arık, 2011: 66), and similar to other sign languages it exhibits morphological agreement with double and single agreement verbs. In order to determine whether inflectional reduction can be observed in commands, we investigated agreement verbs (Padden, 1988), where the two arguments of the verb are marked via spatial modification. This group includes verbs such as give, take, pay, and show (Sevinç, 2006; Kubus, 2008).

We observed that verb agreement with the $2^{\text {nd }}$ person subject is expressed nonmanually in commands with head tilt where the direction of the head tilt parallels the direction of the movement path of agreement verb. This is shown in (4) below.

(4) a.

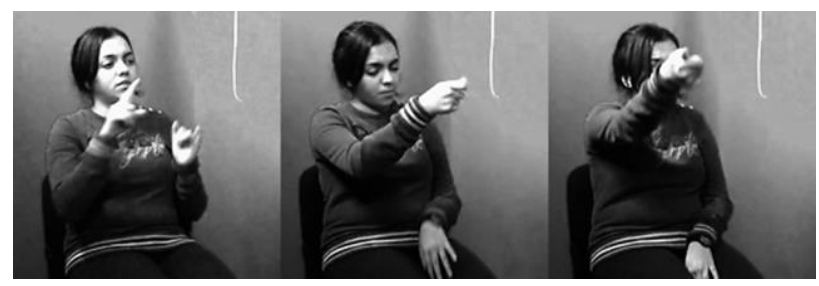

ht

b. $\quad \mathrm{IX}_{2}$

${ }_{2} \mathrm{PAY}_{3}$

'Pay (your debt) to him/her!'

We hence conclude that reduction of subject agreement is not a distinguishing property of commands in TID.

\section{Nonmanual Markers of Commands}

As noted above, we have found the head-related non-manual markers-labeled as 'head nod', 'inclined head' and 'forward head lean' reported for other sign languages (NGT: Maier et al., 2013; LIS: Bonifacio et al., 2011) to be the most distinctive feature of commands in TID. In her description of the command construction in TID, Açan (2007: 223) had previously observed brow position (furrowed brows and/or eyebrow raise).

The nonmanual marker associated with TID commands is head tilt. As illustrated in (5) below, TID commands are formed with a single 
(forward/sideward) head tilt which is co-articulated with the verb and with eye gaze directed towards the addressee ${ }^{11}$.

(5) a.

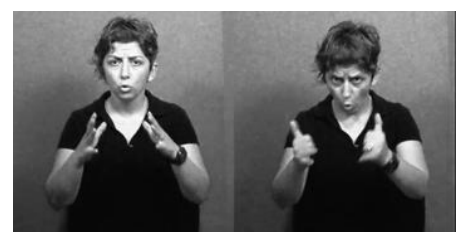

ht

b. BALL PLAY

'Play ball!'

Significantly, we have also noted that the direction of the single head tilt in commands is conditioned by the category of the verb. In commands - as well as instructions and suggestions - with agreement verbs the head tilt, which is coarticulated with the verb, parallels the direction of the movement of the hand towards the goal/theme argument. A similar agreement path is not observed in plain verbs. In this regard head tilt in commands differs from head tilt in declaratives as is illustrated in the contrast between (6) and (7), respectively.

(6) a.

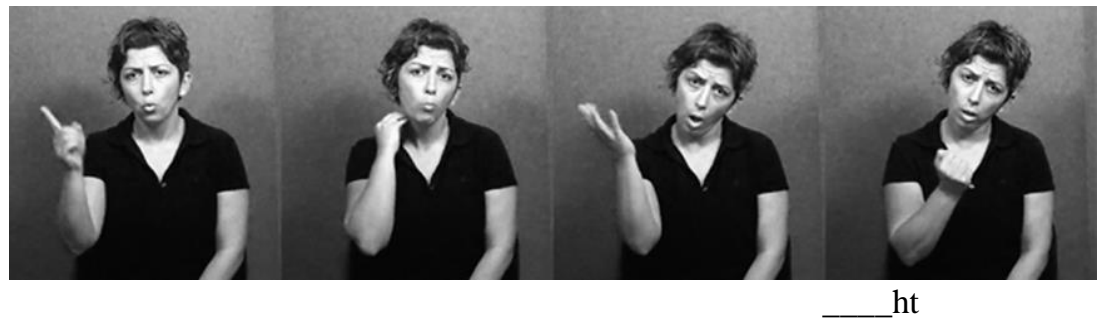

b. IX

LOAN

TAKE

'Let him borrow some money.'

11 We label this nonmanual marker as head tilt rather than head-thrust or head-nod (cf. Zeshan, 2003: 53-54). Given the forward or sideward nature of the head movement as discussed in the text, we hold that the term head tilt better captures the nature of the nonmanual. Hence, head tilt in this paper stands for forward or sideward head tilt observed as co-occurring with verbs and is argued to be the distinctive marker of commands whereas backward head tilt (bht) is the nonmanual marker frequently occurring in negative structures in TID. 
In (6) (command) but not in (7) (declarative), head tilt parallels the direction of the hand movement expressing the agreeing verb (final frame of the visual).

(7) a.

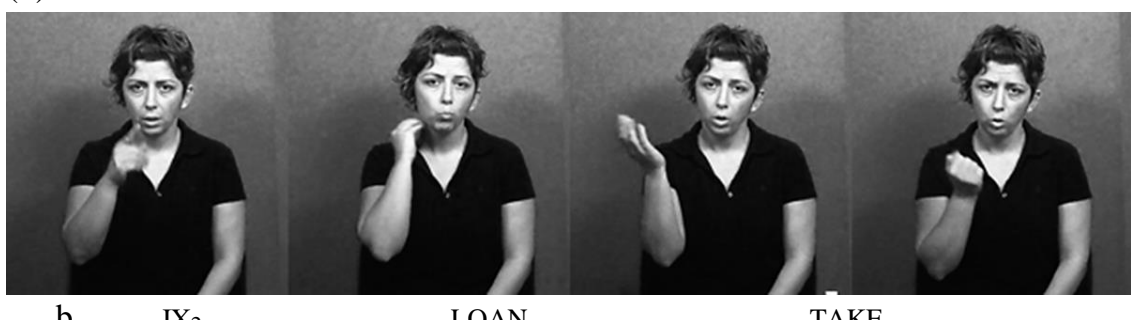

b.

$\mathrm{IX}_{2}$

LOAN

TAKE

'You borrowed some money.'

We take the contrast between (6) and (7) as evidence that single head tilt exhibits properties unique to command constructions (and possibly imperatives, in general) in TID. The head is forward with plain verbs as observed in (5), but sideward with agreeing verbs ${ }^{12}$. Importantly, no sideward head tilt occurs with agreeing verbs in declaratives.

Another distinctive property of head tilt is that its intensity shows gradation across different functions. It is most abrupt in commands, with gradual relaxation of intensity/abruptness from commands to instructions/suggestions.

Based on the fact that head tilt has been observed consistently across participants and the majority of our participants were consistent in producing head tilt in all occurrences of command, we hold that the nature of the head tilt (forward with plain verbs and sideward with agreement verbs) is closely related to the properties of the command construction and that head tilt seems to be the main distinctive morphological marker of commands in TIDD.

\section{Syntactic Properties of Command Constructions}

In this section we look at two syntactic phenomena that are potential candidates to marking commands in TID: (i) the presence/absence of subject pronouns in commands, and (ii) the properties of negative commands.

\subsection{Subject Pronouns}

The literature on spoken languages has shown that if a particular language allows an overt subject in imperatives, it can only be the 2 nd person pronoun, a

12 Whether head forward marks agreement with the addressee in these instances needs to be tested. 
bare noun phrase (proper names and bare nouns) or certain quantificational subjects (Donati \& Branchini, 2012). Crucially, Portner (2007:361) states that if an imperative is used to convey a command, only the 2 nd person pronoun is possible as an overt subject. As for sign languages, Valli \& Lucas (1992: 142143) have reported for ASL imperatives that the subject is often omitted or it follows the verb. Similarly, in NGT the subject is dropped in imperative constructions (Maier et al. 2013).

Our TID consultants had a tendency to drop the 2 nd person subject pronoun in utterance-initial position, but preferred to produce it in utterance-final position, if at all ${ }^{13}$. Since TID has been argued to be a pro-drop language (Sevinç, 2006: 63-64), we refrain from claiming that the absence of an utterance-initial 2 nd person subject pronoun to be a unique syntactic property of commands. Moreover, a possible but less frequent occurrence of subject doubling was also reported by our consultants.

\subsection{Negative Commands}

In some spoken languages, the negative form of the imperative is marked differently from negative declaratives. For instance, some languages must use a subjunctive or an infinitive modified with a negative marker, instead of negating the affirmative imperative form (Iatridou, 2008). In our data, we observed that the form of the verb in negative commands does not differ from that in negative declaratives. This holds true for both simplex and complex predicates, i.e. a verb followed by do $^{\wedge}$ not $^{14}$. Negation can come after both types of predicates. See the figure below:

13 As a representative case we can refer to the production of one of the participants by whom the sentence final subject pronoun was retained only in 8 out of 27 scenarios produced with command constructions.

14 Complex predicates in TID are formed by the sign of the lexical verb and the sign for DO which functions as the AUX element. Regarding the forms with the negative auxiliary (VERB DO^NOT) in commands, no restrictions with respect to verb categories, plain or agreement verbs, were observed in the data. The complex predicate VERB DO ${ }^{\wedge}$ NOT seems to occur freely in negative commands. Further, although the affirmative counterparts of the negative auxiliary (e.g., "Do break!") have not been encountered in the data, it has nevertheless been reported as possible by our participants. 
(8) a.

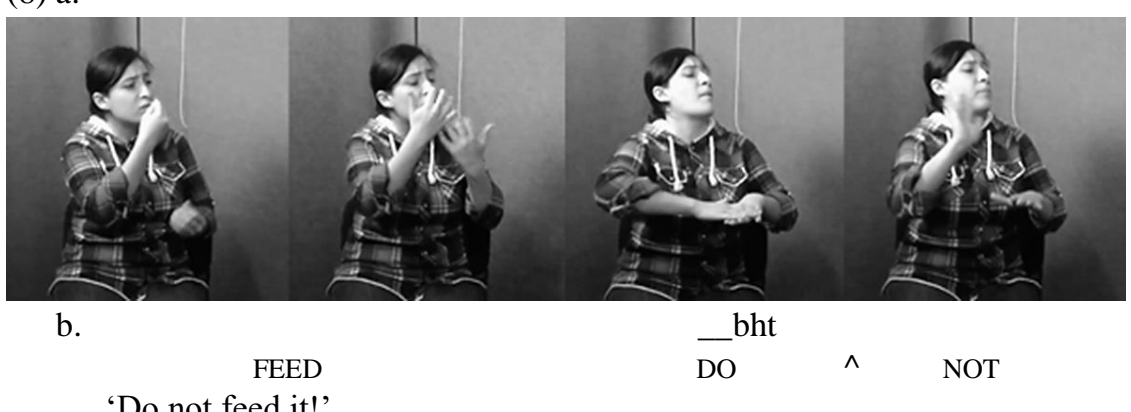

'Do not feed it!'

The example in (8) illustrates that the negative form of complex predicates is formed by the cliticization of the negative marker to the verb $\mathrm{DO}^{15}$. An alternate construction would be an example like in (9) where negation follows the simple verb feed.

\section{(9) FEED $^{\wedge}$ NOT}

'Do not feed it!'

Given that the verb negation strategy found in commands does not differ from that in declaratives, we conclude that negation does not provide sufficient evidence for the presence of an imperative construction in TiD (in the sense of Iatridou, 2008 mentioned in 3.2).

\section{The Function of PALM-UP}

In many sign languages, PALM-UP has been observed to be a distinctive marker of the command (or the imperative) construction. The PALM-UP in TiD has the form of an open flat hand (x-handshape) with the palm facing upwards. It comes after an utterance-final verb. It can be attached to the verb it follows or be articulated as an independent sign with a clear break (pause) after the verb. In the latter case, the utterance ends with a single forward head tilt and an optional eye blink on the verb. The head tilt is articulated simultaneously with the production of PALM-UP in these instances. The utterance in (10) shows an instance of PALM-UP following the verb.

15 One possible analysis of this construction is that it is action topicalization with VERB DO^NOT. Whether that is indeed the case needs further research and as such is beyond the scope of this paper. 
(10)
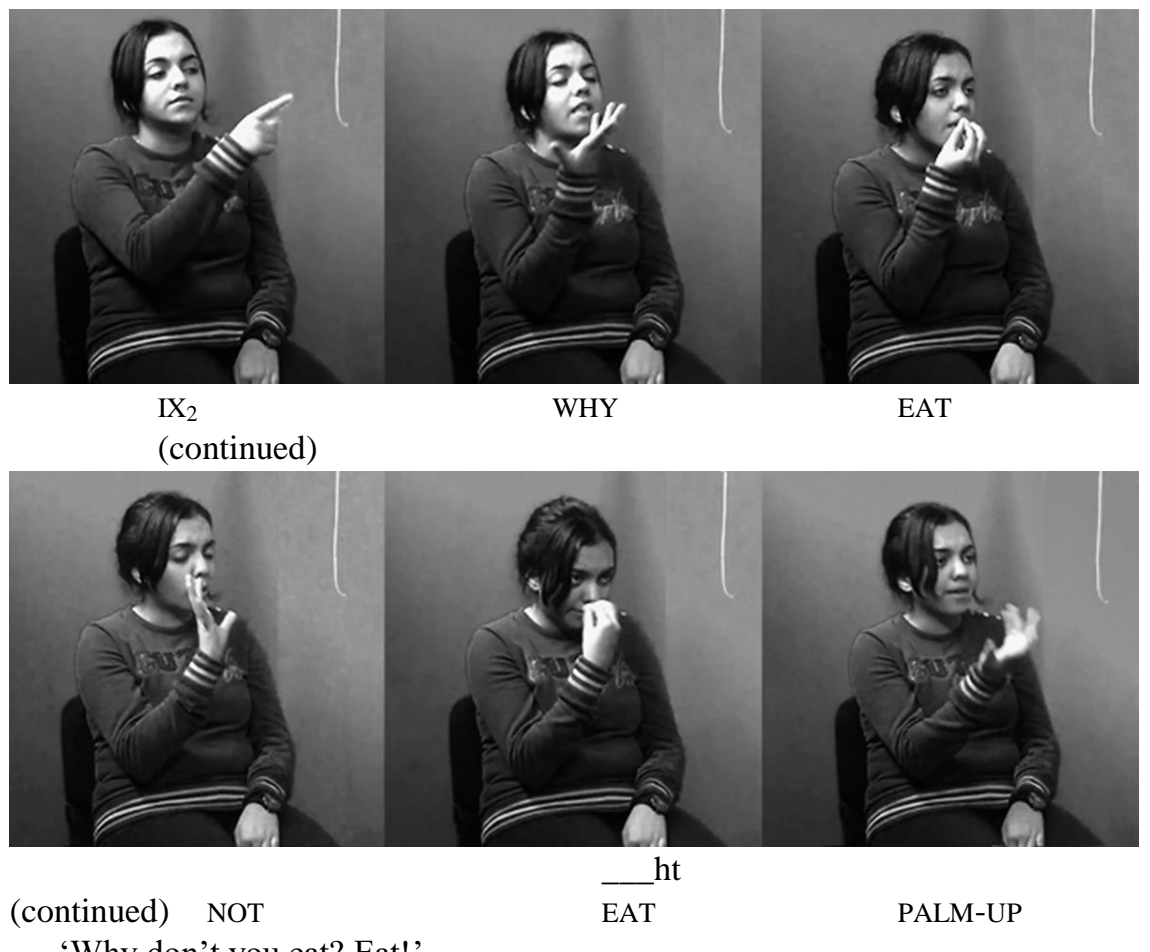

'Why don't you eat? Eat!'

With respect to its articulatory properties, PALM-UP is more commonly signed with one hand, but instances in which both hands are used are also observed. In most cases, this is due to assimilation with the previous double-handed sign. We have observed the following variations of PALM-UP in TID ${ }^{16}$ :

(i) a one-handed verb can be followed by a one-handed PALM-UP,

(ii) a two-handed verb can be followed by two-handed PALM-UP,

(iii) a two-handed verb can be followed by a one-handed PALM-UP.

PALM-UP can also partially assimilate in location and handshape to the previous verb sign, but this is not consistent. We, however, hold that PALMUP is not a distinctive feature of the command construction in TID. It has not

16 Visuals for PALM UP and verb classes are given in Appendix. 
been observed consistently across participants ${ }^{17}$. Moreover, even a single participant was not consistent in signing the PALM-UP with all commands but produced it mainly to convey impatience with the addressee or strong obligation on the part of the addressee to carry out the action of the command. Maier et al. (2013) point out that in NGT, PALM-UP resembles co-speech gestures and consider it to be a discourse particle rather than a linguistic sign. We propose that the PALM-UP found in TID commands has a function similar to the PALM-UP in NGT, i.e. it is not a construction-marking particle but possibly a co-speech gesture, reflecting the emotional state of the signer. In conclusion, we hold that PALM-UP is not a manual sign that exclusively marks commands (or imperatives) in TID.

\section{Conclusion}

In this paper we focused on production data from a total of 10 fluent signers of TID with the aim to provide a linguistic description of commands. We conclude that forward or sideward head tilt appears to be the only salient marker of commands in TID, and that it shows variation in intensity and abruptness across functions decreasing gradually from commands to suggestions. Other potential markers such as subject agreement reduction, negative forms specific for commands or a manual marker such as PALM-UP were not observed to be the properties that identify the construction as a command.

We note that future research in the following areas along the lines laid out in this study will shed further light on the properties of TID and contribute to a more comprehensive description of the language:

(i) How do TID signers distinguish between the perfective/ imperfective declarative constructions and command constructions? Is the distinction expressed manually or nonmanually?

(ii) If the former, i.e. the distinction between the constructions is expressed by means of manuals, what are the properties of the manual markers that are distinctive in differentiating between the different constructions? Is it the duration of the manual marker? Is it its repetitiveness?

(iii) If the distinction between the constructions is expressed nonmanually, what are the nonmanuals that are specific to each construction? Do the nonmanuals differ from those described for commands as described in the present study? If yes, in what way do they differ? If the nonmanuals are of the type, then what property of the NMM distinguishes

17 PALM-UP was produced only in 10 out of 27 command constructions by one of the participants in reacting to scenarios with command task. The other cases include even more scarce occurrences of this form. 
between the constructions? Is it the strength of the prosodic cues? Is it the frequency of the nonmanuals?

(iv) How are the other functions of imperatives - i.e. permission, conditional - expressed in TID? What are the properties that distinguish each function from the other?

\section{References}

Açan, Z. (2007). A linguistic analysis on basic sentence types in Turkish Sign Language (TID) with reference to non-manual activity. $\mathrm{PhD}$ dissertation, Hacettepe University.

Aikhenvald, A.Y. (2012). Imperatives and commands. Oxford: Oxford University Press. Alba, C., Aliaga, D., Barberà, G., Frigola, S., \& Quer, J. (2013) In search of imperatives in Catalan Sign Language (LSC). Paper presented at Workshop on SL Imperatives, WG2 SignGram. Boğaziçi University, Istanbul, 30 May 2013.

Bonifacio E., Capiotto, M., Chistè, M., \& Quartana, G. (2011). Analisi delle tipologie di imperative nella Lingua dei Segni Italiana. Ms. Università Ca' Foscari Venezia.

Brentari, D., Falk, J., Giannakidou, A., Herrmann, A., Volk, E., \& Steinbach, M. (2018). Production and Comprehension of Prosodic Markers in Sign Language Imperatives. Frontiers in Psychology. https://doi.org/10.3389/fpsyg.2018.00770

Brynjólfsdóttir, E.G., \& Jónsson, J. (2013). Imperatives in ÍTM. Paper presented at Workshop on SL Imperatives, WG2 SignGram. Boğaziçi University, Istanbul, 30 May 2013.

Cecchetto, C. (2012). Sentence types. In: Roland Pfau, Markus Steinbach and Bencie Woll (eds.) Sign language: An international handbook. Berlin/Boston: De Gruyter Mouton.

Dikyuva, H. (2011). Aspectual non-manual expressions in TID. MA Thesis, University of Central Lanchashire (UCLan).

Dikyuva, H., \& Zeshan, U. (2008). Türk İşaret Dili: Birinci seviye [Turkish Sign Language: Level one]. Nijmegen: Ishara Press.

Donati, C., \& Branchini, C. (2012). Handout at Workshop on imperatives at COST Work Group 2 meeting. Nijmegen University, 21-23 November 2012.

Donati, C., Barbera, G., Branchini, C., Cecchetto, C., Geraci, C., \& Quer, J. (2017). Searching for impreatives in European sign languages. In: D. van Olmen and S. Heimold (eds.) Imperatives and other directive strategies. Amsterdam/Philadelphia: John Benjamins.

Dryer, M. S. (2007). Clause types. In: T. Shopen (ed.) Language Typology and Syntactic Description. Volume I: Clause structure. Cambridge: Cambridge University Press. 224-275.

Gökgöz, K., \& Arık, E. (2011). Distributional and syntactic characteristics of nonmanual markers in Turkish Sign Language (Türk İşaret Dili, TID). MIT Working Papers in Linguistics 62, Proceedings of the 7th Workshop on Altaic Formal Linguistics, 63-78. 
Han, C. (2000). The sructure and interpretation of imperatives: Mood and force in Universal Grammar. Outstanding Dissertations in Linguistics. New York: Garland Publishing.

Iatridou, S. (2008). De modo imperativo. Lecture notes, ENS, Paris, September 16-19, 2008.

Iatridou, S. (2012). Seminar on imperatives. COST Work Group 2 meeting. Nijmegen University, 21-23 November 2012.

König, E., \& Siemund, P. (2007). Speech act distinctions in grammar. In: T. Shopen (ed.) Language Typology and Syntactic Description. Volume I: Clause structure. Cambridge: Cambridge University Press. 276-342.

Kubus, O. (2008). An analysis of Turkish sign language (TID) phonology and morphology. MSc. Thesis, Middle East Technical University.

Maier, E., K. de Schepper, \& Zwets, M. (2013). The pragmatics of person and imperatives in Sign Language of the Netherlands. Research in Language 11(4): 359-376.

Mauck, S. (2005). Notes on the typology of imperatives. http://www.georgetown.edu/fac-ulty/portnerp/nsfsite/nsfframeset.htm, Georgetown University.

Meir, I. (1998). Syntactic-semantic interaction in Israeli Sign Language verbs: The case of backwards verbs. Sign Language and Linguistics 1: 3-33.

Özsoy, S., Arık, E., Göksel, A., Kelepir, M., \& Nuhbalaoğlu, D. (2013). Documenting Turkish Sign Language. In: E. Arık (ed.) Current directions in Turkish Sign Language research, 55-70. Newcastle upon Tyne, UK: Cambridge Scholars Publishing.

Özsoy, A. S., Kelepir, M., Nuhbalaoğlu, D., \& Hakgüder, E. (2015). Commands in Turkish Sign Language [Türk İşaret Dili'nde Emir Yapıs1]. Journal of Japanese Linguistics Society, 146: 13-30. Gengo Kenkyu

Padden, C. (1988) [1983]. Interaction of morphology and syntax in American Sign Language (Outstanding Dissertations in Linguistics, series IV). New York: Garland Press

Portner, P. (2004). The semantics of imperatives within a theory of clause types. Proceedings of Semantics and Linguistic Theory 14, 235-252.

Portner, P. (2007). Imperatives and modals. Natural Language Semantics 15(4): 351383

Rutkowski, P. (2013). Imperatives in Polish Sign Language (PJM). Paper presented at Workshop on SL Imperatives, WG2 Sign-Gram. Boğaziçi University, Istanbul , 30 May 2013.

Schröder, B.S., Schröder, O.-I., \& Halvorsen, R.P. (2013). On imperative in Norwegian Sign Language (NSL). Paper presented at Workshop on SL Imperatives, WG2 Sign-Gram. Boğaziçi University, Istanbul, 30 May 2013.

Sevinç, A.M. (2006). Grammatical relations and word order in Turkish Sign Language (TiD). M.S.Thesis, Middle East Technical University.

Sloetjes, H., \& Wittenburg, P. (2008). Annotation by category - ELAN and ISO DCR. In: Proceedings of the 6th International Conference on Language Resources and Evaluation (LREC 2008) 
Valli, C., \& Lucas, C. (1992). Linguistics of American Sign Language. Washington: Gallaudet University Press.

von Fintel, K., \& Iatridou, S. (2010). What is in Mediterranean imperative. A presentation based on a keynote address to the $2^{\text {nd }}$ Mediterranean Meeting in Athens, Greece, October 8-10, 2010.

von Fintel, K., \& Iatridou, S. (2012). Imperative puzzles. Slides for the paper presented at the Linguistic Colloquium, Amherst, 9 March 2012.

von Fintel, K., \& Iatridou, S. (2017). A modest proposal for the meaning of imperatives. In: Arregui, Ana, Maria Luísa Rivero \& Andrés Salanova (eds.) Modality Across Syntactic Categories. Oxford: Oxford University Press. 288-319.

Wilbur, R. (2010). The semantics-phonology interface. In: D. Brentari (ed.) Sign languages, 355-380. Cambridge: Cambridge University Press.

Zanuttini, R. (2008). Encoding the addressee in the syntax: Evidence from English imperative subjects. Natural Language and Linguistic Theory 26(1): 185-218.

Zeshan, U. (2002). Sign Language in Turkey: The story of a hidden language. Turkic Languages 6(2): 229-274.

Zeshan, U. (2003). Aspects of Türk İşaret Dili (Turkish Sign Language). Sign Language and Linguistics 6(1): 43-75.

Zhang, S. (1990). The status of imperatives in theories of grammar. $\mathrm{PhD}$ dissertation, University of Arizona.

\title{
Abbreviations \& Conventions
}

$\begin{array}{ll}2 & \text { Adressee } \\ 3 & \text { Non-participant } \\ \text { AUX } & \text { Auxiliary } \\ \text { ht } & \text { HEAD-TILT } \\ \text { IX } & \text { Index } \\ \text { SL } & \text { Sign language } \\ \wedge & \text { Cliticization } \\ \text { ASL } & \\ \text { ÍTM } & \text { Íslenskt táknmál } \\ \text { LIS } & \text { Lingua Italiana dei Segni } \\ \text { LSC } & \text { Llengua de Signes Catalana } \\ \text { LSF } & \text { Langue des Signes Française } \\ \text { NGT } & \text { Nederlandse Gebarentaal } \\ & \\ \text { NSL } & \text { Norsk tegnspråk/NTS } \\ \text { PJM } & \text { Polski Język Migowy } \\ \text { Tİ } & \text { Türk İsaret Dili }\end{array}$

\author{
American Sign Language \\ Icelandic Sign Language \\ Italian Sign Language \\ Catalan Sign Language \\ French Sign Language \\ Sign Language of the \\ Netherlands \\ Norwegian Sign Language \\ Polish Sign Language \\ Turkish Sign Language
}




\section{Appendix - PALM UP and Verb Classes}

Figure 1. One-handed verb followed by a one-handed PALM-UP

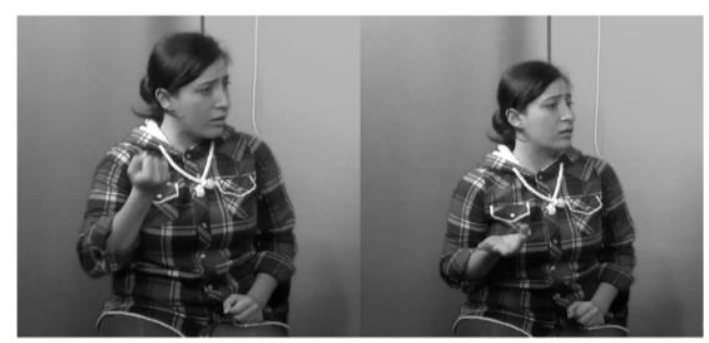

TAKE

PALM-UP

Figure 2. Two-handed verb followed by a one-handed PALM-UP

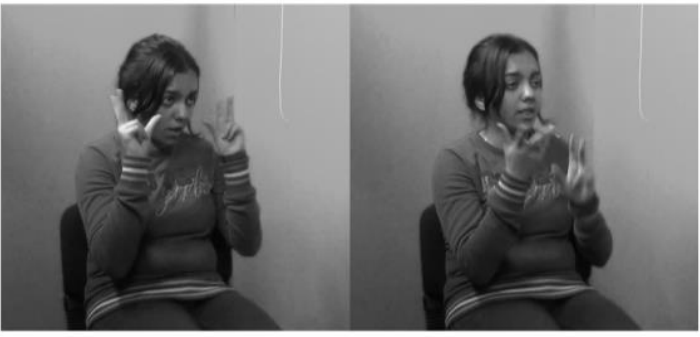

WAKE-UP

PALM-UP

Figure 3. Two-handed verb followed by two-handed PALM-UP

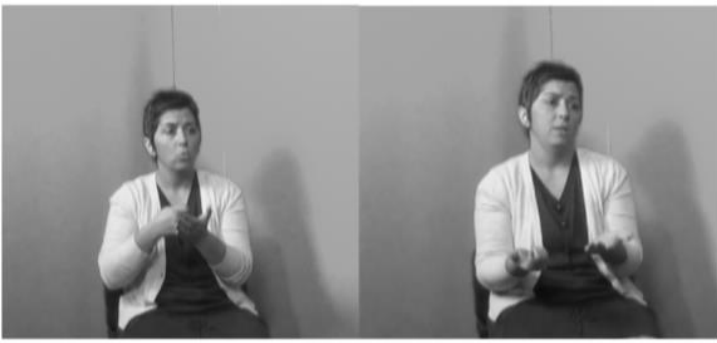

PAY

PALM-UP 